\title{
STUDYING THE JUDGEMENT SAYINGS IN $Q$
}

Book Title:

The Historical Jesus and the final judgment sayings in $\mathrm{Q}$

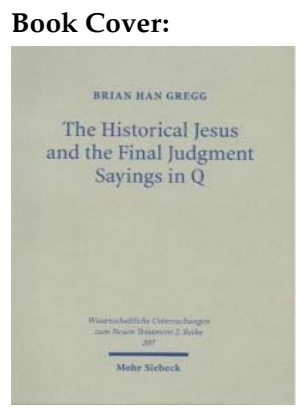

Author:

Brian H. Gregg

Publisher:

Mohr Siebeck, Tübingen,

2006, pp. xiv, 346, €64.00*

*Book price at time of Review

Review Title:

Studying the judgement sayings in $\mathrm{Q}$

\section{Reviewer:}

John S. Kloppenborg ${ }^{1}$

\begin{abstract}
Affiliation:
${ }^{1}$ Department for the Study of Religion, University of Toronto, Canada
\end{abstract}

email:

john.kloppenborg@utoronto.ca

\section{Postal address:}

6 Hoskin Avenue, Toronto, Ontario, M5S 1H8 Canada

How to cite this book review: Kloppenborg, J.S., 2010, 'Studying the judgement sayings in Q', HTS Teologiese Studies/Theological Studies 66(1), Art. \#990, 2 pages. DOI: 10.4102/hts.v66i1.990

\section{This review is available} at:

http://www.hts.org.za

\section{(c) 2010. The Authors.} Licensee: OpenJournals Publishing. This work is licensed under the Creative Commons Attribution License.
Eschatology, the Sayings Gospel Q and the historical Jesus have made for a confusing mixture. Most of the recent specialist studies of the composition and thought of the Sayings Gospel, regardless of what they conclude about Q's eschatology, have quite self-consciously been about $Q$ and not the historical Jesus. Yet for reasons that remain obscure, many of those who use $Q$ studies or wish to detract from $Q$ studies conclude that they really are about Jesus, thus concluding, rather bizarrely, that the stratigraphic studies of $Q$ that stress the sapiential genre of its formative elements are in fact covert claims that the historical Jesus is 'merely' a sage. I say 'bizarre', as they would not, presumably, confuse Mark's portrait of Jesus with the historical Jesus. One of the great virtues of this revised 2005 Notre Dame dissertation, supervised by David E. Aune, is that Gregg keeps clearly distinguished issues of the composition and redaction of $Q$ from the authenticity of sayings contained in $Q$, regardless of what redactional level they occupy. As I argued in 1987 (The Formation of Q [Fortress Press, Philadelphia]), the assigning of a saying or story to a secondary level of redaction was not tantamount to an argument against its authenticity, nor contrariwise was the positing of a saying in the formative level a tacit claim that it came from Jesus. But keeping the questions of history and composition separate, Gregg raises the questions of historicity that most $Q$ specialists have avoided, but has contributed to alleviating rather than perpetuating the methodological confusions rife about $\mathrm{Q}$ and Jesus.

Gregg begins with a helpful typology of scholarship on the authenticity of the judgment sayings in Q: the Jesus Seminar, J.D. Crossan, Burton Mack and Marcus Borg argue that none of the judgment sayings is authentic; E.P. Sanders and Jacques Schlosser admits a very small number of judgment sayings; G.B. Caird, followed by N.T. Wright, interpret the judgment sayings non-eschatologically and others, such as B. Ehrman, D. Allison, Ben Meyer, Scot McKnight, J. Becker and Rainer Reiser, argue that the judgment sayings are substantially authentic, although, as Gregg observes, this case is often made not by arguing individually for the authenticity of sayings, but by pointing to the widespread nature of appeals to final judgment in the tradition.

Gregg provides individual analyses of twelve $Q$ pericopae: $Q$ 6:47-49; 10:10-12, 13-15; 11:31-32; 12:4-5, 8-9, 10, 42-46; 13:28-29; 17:1-2, 26-30, 33. He excludes from his treatment several types of sayings:

- sayings that might be thought to appeal to the judgment but which could be interpreted otherwise (Q 6:20-23; 6:37-38; 11:49-51; 12:58-59; 13:30; 13:34-35; 14:11; 14:34-35; 17:34-35)

- two son of man sayings which are associated with the final judgment but which do not speak of it directly (Q 12:39-40; 17:23-24)

- Q 22:28-30, which presupposes the judgment but which is about the reward of the disciples

- sayings about which ascription to $Q$ is doubtful (Q 13:26-27;14:16-24; 19:11-27).

Following a summary of the standard criteria for assessing authenticity and a chapter on the typologies of final judgment in second temple Judaism (chap. 2) Gregg provides a detailed and careful examination of the twelve Q sayings (chaps. 3-14). Of these, he concluded that ten have at least two criteria of authenticity in their favour and therefore likely come from Jesus: Q 10:10-12; 10:13-15; 11:31-32; 12:4-5; $12: 8-9 ; 12: 10 ; 12: 42-46 ; 13: 28-29 ; 17: 1-2$ and 17:33.

For each pericope Gregg begins with a bibliographical note, and then discusses the context and meaning of the pericope in Matthew, Luke and Q (and Mark, where a doublet exists). Then he isolates the 'most primitive version of the saying' and then discusses arguments for and against authenticity. For example, Q 10:10-12 in relation to Mark 6:11 (the instruction to shake the dust off one's feet before a town that does not accept the 'workers') is both doubly attested and coheres with other authentic sayings. The criterion of coherence is, in fact, key to Gregg's arguments throughout. In this case he argues that because there is no doubt that Jesus set about to 'cull some sort of following from the people of Israel' it is likely that he had his followers participate in the same function. It should be noted, however, that Q 10:10-11 is more than 'culling' and takes us well beyond the calling of disciples. Nor is there much other evidence that Jesus practice or enjoined the kind of sign that is prescribed by Q 10:10-11 (Gregg can only offer the disruption of the temple as a comparable 'sign'). Hence, his case for coherence is far from compelling.

Gregg considers the main argument against authenticity - the thesis of M.E. Boring and others that Q 10:10-11 is the saying of a Christian prophet. But, he argues, there are no grounds for imputing the prophetic action of shaking dust from one's feet to an early prophet rather than to Jesus. Moreover, to doubt the authenticity of the saying on the grounds of its appeal to a threat judgment, as the Jesus Seminar has done, is a petitio principiis.

Q 10:12 (often ascribed to Q redaction) is of course not doubly attested and it is this part of the unit that contains the explicit judgment motif. Gregg resists ascribing it to the redaction that joined Q 10:13-15 to 10:10-11 - indeed he is resistant to speak of $\mathrm{Q}$ redaction at all. By arguing that $\mathrm{Q} /$ Matthew 11:23b-24 is from $Q$, he finds a second attestation of 10:12 within $Q$ and for that reason is inclined to see 10:12 as authentic. The main difficulty with this line of reasoning is that it is difficult to determine whether Matthew 11:23b-24 is a (Matthaean) redactional reiteration of Q 10:12, or whether Q/Matthew 11:23-24 belonged to the $Q$ woes against the Galilean towns and $Q$ 10:12 was the redactional 'glue' that joined 10:10-11 with 10:13-15 (in neither case do we have double independent attestation), or whether $\mathrm{Q}$ 10:10-11.12 and 10:13-15 + Q/Matthew 11:23b-24 were originally independent and partially parallel construction, each ending with a threat of judgment. Gregg opts for the latter solution, but it is not clear that he has sufficiently ruled out either of the two other possibilities. 
In the case of Q 10:13-15, Gregg lacks multiple attestations and tries to make a case from dissimilarity and coherence. He contends that it is unlikely that later Christians would compose a woe against these three Galilean towns for which 'there is absolutely no record of a Christian mission ... in the letters of Paul, the later writings of the New Testament or the Apostolic Fathers' (p. 118) - an odd argument, as neither Paul nor Ignatius of Antioch nor Clement had anything to do with the Galilee and so could not be expected to mention it. But he also argues that the negative view that Q 10:13-15 has of the Gentile cities of Tyre and Sidon does not match the view of the 'early church'. Apparently Gregg means the Pauline and post Pauline churches, dominantly Gentile churches. But $Q$ has an exclusively Judaeo-centric view and elsewhere takes a negative view of Gentiles ( $Q$ 6:32-33; $12: 30$ ), treating what positive responses they might have evinced (Q 7:1-10; 11:31-32) or might be imagined to make (10:13-15) as wholly exceptional. They are responses which shame Israel. This is not unusual rhetoric at all, but mimics that of Ezekiel 16 where the prophet argues that the sins of Sodom and Samaria pale in comparison with those of Jerusalem and that Jerusalem has 'made judgment favorable to [Samaria and Sodom]; because of your sins in which you acted more abominably than they, they are more in the right than you' (16:52). Q's rhetorical posture in
10:13-15 only gets us to a Judaean speaker who argues in the vein of Ezekiel. It does not get us to Jesus.

Gregg's argument from coherence assumes (against E.P. Sanders) that a call to repentance was central to Jesus' mission. One could cite (as Gregg does) Q 11:31-32, but there the Ninevites' repentance is only an illustration of a positive response to the kingdom, parallel to the Queen' the South's pilgrimage to see Solomon. There is no reason to believe from $Q 11: 31-32$ that repentance was programmatic for $\mathrm{Q}$ (or Jesus). Repentance was unquestionably part of John's preaching, but if Claire Rothschild (Baptist Traditions and Q [2005, Mohr Siebeck, Tübingen]) is even partially right (and I think that she is only partially right) Q's Jesus has been significantly modified by the importation of Baptist characterisations. This makes it very difficult to peer behind $Q$ to Jesus.

Although one may argue with many of Gregg's conclusions, it is nonetheless to be said that this is one of the most clear, careful and able analyses of the possible authenticity of the judgment sayings in $\mathrm{Q}$. Whether one agrees or disagrees, Gregg has raised the discussion beyond vague generalities or dogmatic denials and given us something substantial with which to wrestle. 